\title{
Antimicrobial Efficacy, Cytotoxicity, Acute Oral Toxicity, and Phytochemical Investigation of the Aqueous and Methanolic Stem Bark Extracts of Bridellia micrantha (Hochst.) Baill
}

\author{
Joseph M. Kathare' ${ }^{1, *}$, James M. Mbaria', Joseph M. Nguta', Gervason A. Moriasi' ${ }^{2}$, Alfred O. Mainga'
}

\section{Joseph M. Kathare ${ }^{1, *}$, James \\ M. Mbaria', Joseph M. Nguta', Gervason A. Moriasi' ${ }^{2}$, Alfred O. Mainga ${ }^{1}$}

'Department of Public Health, Pharmacology, and Toxicology, College of Veterinary and Agricultural Sciences, University of Nairobi, P.O. Box 29053Sciences, University of Nair

00625, Nairobi, KENYA.
2Department of Medical Biochemistry, School of 2Department of Medical Biochemistry, School of
Medicine, College of Health Sciences, Mount Kenya University, P.O. 342-01000, Thika, KENYA.

\section{Correspondence}

\section{Joseph Kathare}

Department of Public Health,

Pharmacology, and Toxicology, College

of Veterinary and Agricultural Sciences,

University of Nairobi, P.O. Box 29053-

00625, Nairobi, KENYA

E-mail: murithikathare@gmail.com

History

- Submission Date: 18-05-2021;

- Review completed: 18-06-2021;

- Accepted Date: 22-06-2021.

DOI : 10.5530/pj.2021.13.158

Article Available online

http://www.phcogj.com/v13/i5

Copyright

(C) 2021 Phcogj.Com. This is an openaccess article distributed under the terms of the Creative Commons Attribution 4.0 International license.

\begin{abstract}
Introduction: Microbial infections cause high morbidity and mortality in humans globally. Antimicrobial resistance, emergence of new strains, high costs of antibiotics, inaccessibility-especially in remote areas, and adverse effects, impede successful eradications of pathogens, hence the need for novel strategies. Bridellia micrantha is used in traditional medicine to treat microbial infections; however, it has not been empirically validated. Methods: Antimicrobial activity of the aqueous and methanolic stem bark extracts of Bridellia micrantha was investigated using the disk diffusion and broth microdilution techniques, described by the Clinical Laboratory Standards Institute (CLSI) guidelines. The brine shrimp lethality assay technique was used to investigate the cytotoxic effects of the studied plant extracts in exposed nauplii. Acute oral toxicity effects of the studied plant extracts in Winstar rats were investigated following the up-and-down procedure described by the Organisation for Economic Development and Co-operation (OECD). Qualitative phytochemical screening was performed following standard procedures. Results: The aqueous and methanolic extract of B. micrantha indicated varied antimicrobial activities against $E$. coli, S. typhimurium, $S$. aureus, and $C$. albicans, with inhibition zones ranging from $6.00 \mathrm{~mm}$ to $19.00 \mathrm{~mm}$. Furthermore, the studied plant extracts exhibited low MIC values $(\leq 100 \mu \mathrm{g} / \mathrm{ml})$ on selected microbes. Since the MIC values were much lower than $1000 \mu \mathrm{g} / \mathrm{ml}$ (the cutoff for antimicrobial efficacy appraisal), it is anticipated that, the studied plant extracts can be strong antibiotics. The aqueous and methanolic stem bark extracts of $B$. micrantha were cytotoxic to brine shrimp nauplii, with $\mathrm{LC}_{50}$ values of $486.67 \pm 3.15 \mu \mathrm{g} / \mathrm{ml}$ and $458.33 \pm 2.87$ $\mu \mathrm{g} / \mathrm{ml}$, respectively; however, these extracts did not elicit any observable signs of toxicity in rat models. Pharmacologically active phytochemicals, including flavonoids, alkaloids, saponins, tannins, phenols, and anthraquinones were detected in the two studied extracts. Conclusions: The aqueous and methanolic stem bark extracts of $B$. micrantha have appreciable antimicrobial activity against $E$. coli, S. typhimurium, $S$. aureus and $C$. albicans. Besides, the studied plant extracts are cytotoxic to brine shrimp nauplii; but they do not cause acute oral toxicity effects in rat models. Additionally, the studied plant extracts contain bioactive phytochemicals, with antimicrobial activity.

Key words: Brine shrimp lethality Assay, Minimum inhibitory concentration, Median lethal concentration $\left(\mathrm{LC}_{50}\right)$, median lethal dose $\left(\mathrm{LD}_{50}\right)$, Zone of inhibition.
\end{abstract}

\section{INTRODUCTION}

Microbial infections are among the major causes of morbidity and mortality in humans globally, especially in vulnerable groups ${ }^{1-3}$. Furthermore, the increased rate of antimicrobial resistance to the available medications has caused major healthcare challenges ${ }^{4,5}$. The persistence of microbial infections during and after the treatment cycles has precipitated an overuse of antibiotics leading to other unprecedented outcomes ${ }^{6}$.

Owing to the drawbacks and inefficiencies of conventional antimicrobial chemotherapy, alternative stratagems are required to curb infectious diseases at relatively cheaper costs than those involved in orthodox medicine, and with fewer or no toxic effects ${ }^{7}$. Medicinal plants on the other hand are a valuable source of antimicrobials owing to their long-term applications. Further, these plants are considered to easily accessible, affordable and with fewer side effects compared to western medicine ${ }^{8,9}$.

Bridellia micrantha (Hochst.) Baill is a medium to large deciduous tree which grows up to $20 \mathrm{~m}$ above the ground with spreading crown ${ }^{10}$. It belongs to Euphorbiaceae family of herbs and trees which are characterized by succulent leafless branches; milky or watery latex; glands at the leaf base; and 3-lobed fruits. It is locally known as 'mukuigo' by the Kikuyu of Murang'a County, Kenya ${ }^{11,12}$.

The stem bark tinctures and decoctions of Bridellia micrantha are used to cure burns, soft tissue injuries, sexually transmitted infections, protozoa infections, gastrointestinal conditions, typhoid, pneumonia and dental diseases ${ }^{12,13}$. Leaf preparation is used to manage eye problems ${ }^{13}$.

Previous studies have indicated that $B$. micrantha has anti-ulcer activity against $H$. pylori-induced ulcers and antimicrobial activities against S. typhi, S. enteritidis, S. flexneri, E. coli and M. tuberculosis bacterial strains ${ }^{13}$. Furthermore, antidiabetic, hypolipidemic and antioxidant effects of extracts derived from $B$. micrantha have been reported ${ }^{10,14}$. Phytochemical investigations have revealed presence oftaraxerone, Friedelin, Taraxerol, Epifriedelinol, gallic acid, ellagic acid, anthocyanidin, delphiniridin and Benzene 1,3-bis(3-phenoxyphenoxy),2-pinen-4-one ${ }^{13}$. 
In spite of the extensive usage of medicinal plants to curb microbial infections, there are few focused empirical studies formulated to validate the claimed potencies ${ }^{15}$. Moreover, due to the lack of clear dosage regimens, formulation guidelines, marketing and practice regulations in traditional medicine practice, toxicity and safety profiles of most medicinal plants have remained unknown ${ }^{16}$.

Therefore, this study was designed to investigate the antimicrobial, cytotoxicity and acute oral toxicity effects of the aqueous and methanolic stem bark extracts $B$. micrantha to lay a framework towards their validation and as potential sources of safe and potent antimicrobials.

\section{MATERIALS AND METHODS}

\section{Plant collection, identification, and processing}

The stem barks of the studied plants were selected for this study based on their ethnomedical usage among the Agikuyu community of Muranga County ${ }^{12}$. The plant specimen was submitted to the East African herbarium hosted at the National Museum of Kenya in Nairobi and botanically identified and authenticated by a taxonomist at National Museums of Kenya and assigned voucher specimen numbers as follows; Bridellia micrantha (NMK/01/2019), where the voucher specimens were prepared and deposited. The plant materials were then collected and transported to the Department of Public Health, Pharmacology and Toxicology laboratories, at the College of Agriculture and Veterinary Sciences, Kabete Campus, University of Nairobi. The collected materials were then sorted and evenly spread to dry at room temperature for 2 weeks. They were then ground into a powder by an electric mill and stored in plastic containers awaiting extraction.

\section{Extraction of the collected plant materials}

The crude extracts of the studied plant materials were prepared according to the procedures described by Harborne ${ }^{17}$. The methanolic extracts of the studied plant materials were obtained by cold maceration method. Briefly, $250 \mathrm{~g}$ of respective plant powders were soaked in 1 litre of analytical-grade methanol in 2-litre conical flasks. The respective flasks containing the merc-menstruum mixtures were gently shaken and covered with aluminum foil papers at their mouths. They were shaken once daily for two days, thereafter, the mixtures were decanted and filtered through Whatman filter papers (No.1). They were then concentrated under vacuum by the help of a rotary evaporator. The resultant extracts were transferred into glass bottles and further dried in a hot-air oven at $35{ }^{\circ} \mathrm{C}$ for 5 days. They were weighed and their respective percentage yields determined.

For the aqueous extracts, about $50 \mathrm{~g}$ of respective plant powders were macerated in $500 \mathrm{ml}$ of distilled water and heated for minutes at 58 ${ }^{\circ} \mathrm{C}$. The mixtures could cool to room temperature and then filtered through the Whatman filter papers. The filtrates were transferred into freeze-drying flasks and fitted into a freeze-dryer, where they were lyophilized for $48 \mathrm{hrs}$. The dried extracts were weighed, and their respective percentage yields determined. All the extracts were stored in a refrigerator $\left(4^{\circ} \mathrm{C}\right)$ and only retrieved when required.

Investigation of the antimicrobial activities of the aqueous and methanolic bark extracts of $B$. micrantha on selected microbes

In this study, Escherichia coli (ATCC 25925), Salmonella typhimurium, (ATCC 14028), Staphylococcus aureus (ATCC 25923) and C. albicans (ATCC 10231) were obtained from the Department of Public Health, Pharmacology and Toxicology of the College of Agriculture and Veterinary Sciences, University of Nairobi, Kabete Campus. These strains were selected based on their clinical significance and availability. To investigate the effects of the studied plant extracts on the selected microbial strains, the disc diffusion and broth microdilution techniques described by the Clinical and Laboratory Standards Institute were followed ${ }^{18}$.

\section{Preparation and standardization of microbial inoculum for experimentation}

The fungal strain (C. albicans) was grown in Sabouraud dextrose agar (SDA; Oxoid) for $24 \mathrm{hrs}$ according to the directions of the M100-S23 document of the CLSI ${ }^{18}$. Thereafter, sterile normal saline was used to standardize the inoculum to achieve a $0.5 \mathrm{McFarland}$ standard at 530 $\mathrm{nm}$ using a UV-vis spectrophotometer. Ranges of between 0.11 and 0.14 at $\mathrm{OD}_{530}$ were obtained. This was considered to be $1-5 \times 10^{6} \mathrm{cfu} / \mathrm{ml}$.

On the other hand, the bacterial strains (E. coli, S. typhimurium and S. aureus) were grown in Mueller-Hinton agar as per the CLSI guidelines for $24 \mathrm{hrs}$. Thereafter, the inocula were standardized to a turbidity equivalent to $0.5 \mathrm{McF}$ arland scale of approximately $1-2 \times 10^{8} \mathrm{cfu} / \mathrm{ml}^{18}$.

\section{The disc diffusion assay for antimicrobial susceptibility}

In this assay, $1 \mathrm{~g}$ of each of the studied extracts were dissolved in $10 \mathrm{ml}$ of $1 \%$ DMSO (in sterile water) in a $15 \mathrm{ml}$ centrifuge tube and thoroughly vortexed to make stock solutions of containing $100 \mu \mathrm{g} / \mathrm{ml}$. The stocks were then serially diluted two-fold to give $50 \mu \mathrm{g} / \mathrm{ml}, 25 \mu \mathrm{g} / \mathrm{ml}, 12.5 \mu \mathrm{g} /$ $\mathrm{ml}, 6.25 \mu \mathrm{g} / \mathrm{ml}$ and $3.125 \mu \mathrm{g} / \mathrm{ml}$ respectively.

Afterwards, $20 \mu \mathrm{l}$ were aspirated and carefully impregnated on sterile Whatman discs of $6 \mathrm{~mm}$ diameter. The discs were gently pressed on the media containing $1 \mathrm{ml}$ of the bacterial or fungal inocula to allow for proper drug-microbe contact. The assays were performed in triplicate with DMSO as negative control and streptomycin or ciprofloxacin or amphotericin B as positive controls. All the plates were incubated for 24 hrs at $37^{\circ} \mathrm{C}$, then diameters of zones of inhibition of microbial growth measured in millimeters.

\section{The Broth microdilution technique for minimum} inhibitory concentration (MIC) determination

In this determination, the modified CLSI method described by Golus et al. ${ }^{19}$ was adopted. Briefly, cultures were prepared and adjusted in Mueller-Hinton Broth media to 0.5 McFarland equivalent turbidity. Carefully, $10 \mu \mathrm{l}$ of the previously prepared test extracts at a 10 -fold concentration were transferred into Eppendorf tubes containing 90 $\mu \mathrm{l}$ of molten Mueller-Hinton agar in triplicate and gently vortexed. Microdilution was done in volumes of $100 \mu$ in sterile 96-U-shaped multiwell plates in two-fold. In each of the micro-titre plates, the growth, sterility control and negative ( $1 \%$ DMSO) controls were included for each of the tested microbial strains.

All the multiwell plates could settle at room temperature for the agar to solidify. Then, $2 \mu \mathrm{l}$ of freshly prepared inoculate at concentration of $10^{4}$ $\mathrm{cfu} /$ spot were dispensed into the wells using a multichannel micropipette and allowed to interact at room temperature. The wells at the sides were added sterile water, and the plates were covered in zip-lock plastic bags and incubated at $35{ }^{\circ} \mathrm{C}$ for $18 \mathrm{hrs}$. The MIC was determined as the lowest concentration of the studied extracts which could completely inhibit microbial growth as per the CLSI recommendations ${ }^{18}$.

\section{Evaluation of the effects of the studied plants extracts on brine shrimp nauplii}

In this study, the brine shrimp lethality assay method described by Meyer et al. ${ }^{20}$ was used. Briefly, approximately $0.5 \mathrm{~g}$ of Artemia salina cysts (Sanders Great SaltLake, Brine Shrimp Company L.C., U.S.A.) were placed in an artificial sea containing $500 \mathrm{ml}$ of brine water. They were incubated for two days to hatch into nauplii under continuous normal bulb illumination at $25-29{ }^{\circ} \mathrm{C}$ temperature and enough aeration. 
Thereafter, ten nauplii were transferred using Pasteur pipettes into three sets of sample vials containing the either the studied plant extracts at concentrations of $0,10,100$ and $1000 \mu \mathrm{g} / \mathrm{ml}$ or podophyllotoxin in 5 $\mathrm{ml}$ brine solutions in triplicate. The nauplii were then incubated for 24 hours and the number of survivors in each test vial were counted and documented. The percentage lethality was determined as a ratio of surviving nauplii in the test groups to those in the control (vehicle treated) group. $\mathrm{LC}_{50}$ values were derived from the line of best from a plot of percentage survival against concentration.

Evaluation of the Acute Oral Toxicity effects of the aqueous and methanolic bark extracts of the studied plant extracts

In this study, the guidelines posited by the Organization for Economic Co-operation and Development (OECD) in protocol document number 425 were adopted ${ }^{21}$. Experimental female Winstar Rats weighing $150 \pm$ $20 \mathrm{~g}$ were sourced from the Department of Public Health, Pharmacology and Toxicology animal breeding unit, acclimatized for $72 \mathrm{hrs}$ before dosing. The studied plant extracts were reconstituted in normal saline solution to achieve the appropriate dose for administration.

On the experimentation day, the animals were fasted for $4 \mathrm{hrs}$ and randomly assorted into groups of three rats. The experiment was initiated by administering a single dose of $175 \mathrm{mg} / \mathrm{Kg}$ bw orally to the first group and normal saline $(10 \mathrm{ml} / \mathrm{Kg} \mathrm{bw})$ to the control group.

Observations of wellness parameters (skin fur, eye colour, mucus membrane, salivation, lethargy, sleep, coma, convulsions, tremors and diarrhoea) were recorded at intervals of 30 min., 4 h., 24 h., 48 h., 1 week and 2 weeks for each individual rat. In the absence of observable signs of toxicity or mortality during the 14-day experimentation period, the next subsequent higher doses of $550 \mathrm{mg} / \mathrm{Kg}$ bw and $2000 \mathrm{mg} / \mathrm{kg}$ bw respectively were administered into new groups of rats. All the experiments were done in triplicate ${ }^{21}$. At the end of the experiments, the experimental rats were euthanized and disposed of according to the set protocols.

\section{Qualitative phytochemical composition of the aqueous and methanolic bark extracts of $B$. micrantha}

In this study, the standard protocols for qualitative phytochemical screening described by Harborne ${ }^{20}$ were followed. The phytochemicals that were evaluated include alkaloids, flavonoids, tannins, Saponins, Anthraquinones and phenols.

\section{TEST FOR ALKALOIDS}

\section{Dragendorff test}

About $0.1 \mathrm{~g}$ of theaqueous and methanolic extracts of $B$. micrantha were extracted by boiling with $10 \mathrm{ml}$ of $1 \%$ hydrochloric acid in independent test tubes. The mixtures were filtered and to about $2 \mathrm{ml}$ of the filtrate, a few drops of the Dragendorff reagent were added. The formation of the red precipitates in the respective tubes indicate presence of alkaloids.

\section{Mayer's test}

To the $2 \mathrm{ml}$ remaining portion of the filtrate of the respective extracts in the Dragendorff test, a few drops of the Mayer's reagent were added along the sides of the respective tubes. The formation of the white creamy precipitates in the respective tubes indicated presence of alkaloids.

\section{Test for flavonoids}

To approximately $5 \mathrm{ml}$ of ethanolic filtrates of the respective extracts, $2 \mathrm{ml}$ of $2 \%$ sodium hydroxide were added. The formation of an intense colour that decolorize on addition of a few drops of diluted hydrochloric acid indicate presence of flavonoids.

\section{Test for tannins (ferric chloride test)}

About $0.1 \mathrm{~g}$ of the aqueous and methanolic bark extracts of the studied plants were extracted by boiling with $20 \mathrm{ml}$ of the distilled water. The mixtures were filtered through Whatman filter paper, and into 2 $\mathrm{ml}$ of the filtrate, a few drops of $5 \%$ ferric chloride were added. The appearance of the dark green colour indicates a positive test for tannins.

\section{Test for phenols}

About $0.1 \mathrm{~g}$ each of the studied extracts were boiled with $10 \mathrm{ml}$ of $70 \%$ of ethanol for 5 minutes in water bath and then filtered while hot. The filtrates were cooled to room temperature and $2 \mathrm{ml}$ of it be transferred into a clean test-tube then followed by dropwise addition of $5 \%$ ferric chloride solution. The appearance of green precipitates will indicate the presence of phenols.

\section{Test for saponins}

About $0.5 \mathrm{~g}$ of the aqueous and methanolic extracts of the studied plants were dissolved in $5 \mathrm{ml}$ of warm distilled water and vigorously shaken. The appearance of persistent frothing indicated presence of saponins.

\section{Test for anthraquinones}

Approximately $0.1 \mathrm{~g}$ of each of the studied extract were warmed $1 \mathrm{ml}$ of chloroform in a water bath for 5 minutes. Afterwards, they were filtered through Whatman filter paper and allowed to cool to room temperature before adding equivalent volumes of $10 \%$ ammonia. The mixtures were then shaken and the presence of pink coloration on the upper layer indicates presence of anthraquinones.

\section{Data management and analysis}

Quantitative data from antimicrobial and brine shrimp lethality experiments were tabulated on Excel spreadsheet (Microsoft 365) and exported to Minitab version 19.1 statistical software. Descriptive statistics were performed, and values were expressed as $\bar{x} \pm S E M$ OneWay ANOVA was used to determine differences among means followed by Tukey's post hoc test for pairwise comparisons and separations of means. Means that showed $\mathrm{p}$ values $<0.05$ were considered statistically significant. Acute oral toxicity results were treated according to the OECD $^{21}$ guidelines. Qualitative data on wellness parameters in the acute oral toxicity and qualitative phytochemical screening studies were only tabulated. The obtained findings were presented in tables.

\section{RESULTS}

\section{Antimicrobial effects of the aqueous bark extract of Bridellia micrantha on selected microbial strains}

The antimicrobial effects of the aqueous bark extracts of Bridellia micrantha were also investigated in this study. The results showed that at the lowest three concentrations tested, the mean zones of inhibition in E. coli bacterial strain were not significantly different ( $\mathrm{p}>0.05$; Table 1). Likewise, at the two upper concentrations $(50 \mu \mathrm{g} / \mathrm{ml}$ and $100 \mu \mathrm{g} /$ $\mathrm{ml}$ ), the obtained zones of inhibition of $E$. coli were significantly similar ( $p>0.05)$. However, the positive control antibiotic gave the largest zone of inhibition $(26.67 \pm 0.33 \mathrm{~mm})$ compared with the zones of all the other treatments in E. coli $(\mathrm{p}<0.05$; Table 1$)$.

The effects of the aqueous bark extract of $B$. micrantha on $S$. typhimurium were also investigated in this study, the results revealed no significant difference in zones of inhibition at extract concentrations of $6.25 \mu \mathrm{g} / \mathrm{ml}$ and $12.5 \mu \mathrm{g} / \mathrm{ml}$ and at concentrations of $50 \mu \mathrm{g} / \mathrm{ml}$ and 12.5 $\mu \mathrm{g} / \mathrm{ml}(\mathrm{p}>0.05$; Table 1). Similarly, at a concentration of $3.125 \mu \mathrm{g} / \mathrm{ml}$, the recorded zone of inhibition was not significantly from that of the negative control $(p>0.05)$. However, the positive control drug showed a significantly larger zone of inhibition than the zones produced in all the other treatments $(\mathrm{p}<0.05$; Table 1$)$. 
The effects of the aqueous bark extract of $B$. micrantha on $S$. aureus bacterial strain were determined. In this study, at all the extracts concentrations, the observed zones of inhibition were not significantly different $(p>0.05$; Table 1). However, the reference drug produced a significantly larger zone of inhibition compared with the zones produced by the studied extract at all concentrations and the negative control $(\mathrm{p}<0.05$; Table 1).

The susceptibility of C. albicans fungal strain to the aqueous bark extract of $B$. micrantha was investigated in this study. The results showed no significant differences in zones of inhibition recorded at all the extract concentrations were observed ( $p>0.05$; Table 1$)$. Notably, C. albicans was not susceptible to the reference drug, hence, the zone of inhibition was like that of the negative control ( $\mathrm{p}>0.05$; Table 1$)$.

The effects of the methanolic bark extract of $B$. micrantha on selected microorganisms were also investigated in this study. The results showed that, upon application of $6.25 \mu \mathrm{g} / \mathrm{ml}, 12.5 \mu \mathrm{g} / \mathrm{ml}, 25 \mu \mathrm{g} / \mathrm{ml}$, and $50 \mu \mathrm{g} /$ $\mathrm{ml}$ of the methanolic bark extract of $B$. micrantha, the exhibited zones of inhibition were not significantly different ( $>0.05$; Table 2 ). However, at $100 \mu \mathrm{g} / \mathrm{ml}$, the observed zone of inhibition was significantly larger compared to zones of inhibition in other extract concentrations and negative control $(\mathrm{p}<0.05$; Table 2$)$. In this setup, the positive control showed the highest zone of inhibition compared with all the other zones of inhibition $(\mathrm{p}<0.05$; Table 2$)$.
For S. typhimurium, the exhibited zones of inhibition by the methanolic extract of $B$. micrantha, ranged from $7.33 \pm 0.33 \mathrm{~mm}$ at $3.125 \mu \mathrm{g} / \mathrm{ml}$ to $11.33 \pm 0.67 \mathrm{~mm}$ at $100 \mu \mathrm{g} / \mathrm{ml}$ with significant differences $(\mathrm{p}<0.05$; Table 2). No significant differences in zones of inhibition of $S$. typhimurium were observed in extract concentrations of $12.5 \mu \mathrm{g} / \mathrm{ml}, 25 \mu \mathrm{g} / \mathrm{ml}$, and 50 $\mu \mathrm{g} / \mathrm{ml}(\mathrm{p}>0.05$; Table 2). Generally, a dose-dependent increase in zone of inhibition sizes was observed with the increasing concentration of the extract with $100 \mu \mathrm{g} / \mathrm{ml}$ showing a significantly larger zone than those in lower concentrations $(\mathrm{p}<0.05$; Table 2$)$. In this setup, the positive control drug showed the largest zone of inhibition compared with all the other zones $(\mathrm{p}<0.05$; Table 2$)$.

\section{Minimum inhibitory concentrations (MICs)}

The lowest concentrations of the studied plant extracts and reference antibiotics, which completely inhibited microbial growth in the 48-hr incubation period at $37^{\circ} \mathrm{C}$, were considered as the minimum inhibitory concentrations (MICs).

The MICs of the aqueous bark extract of $B$. micrantha were $50 \mu \mathrm{g} / \mathrm{ml}$ and $100 \mu \mathrm{g} / \mathrm{ml}$ for $E$. coli and S. typhimurium bacterial strains respectively and $12.5 \mu \mathrm{g} / \mathrm{ml}$ for both S. aureus and C. albicans (Table 3). Similarly, the MICs of the methanolic bark extract of $B$. micrantha were $50 \mu \mathrm{g} /$ $\mathrm{ml}$ for E. coli, $100 \mu \mathrm{g} / \mathrm{ml}$ for S. typhimurium and $12.5 \mu \mathrm{g} / \mathrm{ml}$ for both $S$. aureus and C. albicans microbes (Table 3 ).

Table 1: Antimicrobial effects of the aqueous bark extract of Bridellia micrantha on selected microbial strains.

\begin{tabular}{|c|c|c|c|c|}
\hline Concentration $(\mu \mathrm{g} / \mathrm{ml})$ & \multicolumn{4}{|c|}{ Zone of inhibition (mm) } \\
\hline 3.125 & $6.17 \pm 0.17^{\mathrm{d}}$ & $6.67 \pm 0.17^{\mathrm{d}}$ & $10.33 \pm 1.20^{\mathrm{bc}}$ & $11.00 \pm 0.58^{\mathrm{a}}$ \\
\hline 12.5 & $8.50 \pm 1.76^{\mathrm{cd}}$ & $7.00 \pm 0.00^{\text {cd }}$ & $11.33 \pm 1.33^{\mathrm{bc}}$ & $12.17 \pm 0.17^{\mathrm{a}}$ \\
\hline 25 & $10.50 \pm 1.04^{c}$ & $7.83 \pm 0.60^{c}$ & $13.33 \pm 1.67^{\mathrm{b}}$ & $12.67 \pm 1.33^{\mathrm{a}}$ \\
\hline -ve & $6.00 \pm 0.00^{\mathrm{d}}$ & $6.00 \pm 00^{\mathrm{d}}$ & $6.00 \pm 00^{\mathrm{d}}$ & $6.00 \pm 0.00^{\mathrm{b}}$ \\
\hline$+\mathrm{ve}$ & $26.67 \pm 0.33^{\mathrm{a}}$ & $27.00 \pm 0.00^{\mathrm{a}}$ & $24.33 \pm 0.33^{\mathrm{a}}$ & $6.00 \pm 0.00^{\mathrm{b}}$ \\
\hline
\end{tabular}

Values are expressed as $\tilde{x} \pm$ SEM; means which do not share a lowercase alphabet superscript within the same column are significantly different (One-Way ANOVA followed by Tukey's test ( $p<0.05)$; Positive control: For E. coli and S. typhimurium it was Ciprofloxacin (10 $\mu \mathrm{g})$; For S. aureus it was Streptomycin $(\mu \mathrm{g})$ and for C. albicans it was Amphotericin B ( $\mu \mathrm{g})$; Negative control: DMSO (1.4 \%).

Table 2: Antimicrobial effects of the methanolic bark extract of Bridellia micrantha on selected microbial strains.

\begin{tabular}{|c|c|c|c|c|}
\hline \multirow{2}{*}{ Concentration $(\mu \mathrm{g} / \mathrm{ml})$} & \multicolumn{4}{|c|}{ Zone of inhibition (mm) } \\
\hline & E. coli & S. typhimurium & S. aureus & C. albicans \\
\hline 3.125 & $10.00 \pm 1.53^{\mathrm{c}}$ & $7.33 \pm 0.33^{e}$ & $8.33 \pm 0.88^{\mathrm{de}}$ & $6.67 \pm 2.85^{\mathrm{d}}$ \\
\hline 12.5 & $12.67 \pm 2.96^{\mathrm{bc}}$ & $9.33 \pm 0.67^{\mathrm{cd}}$ & $10.67 \pm 1.86^{\mathrm{cd}}$ & $12.00 \pm 0.00^{\mathrm{b}}$ \\
\hline 25 & $13.00 \pm 2.00^{\mathrm{bc}}$ & $10.00 \pm 0.58^{\mathrm{bcd}}$ & $12.67 \pm 0.88^{\mathrm{bc}}$ & $12.33 \pm 0.33^{\mathrm{b}}$ \\
\hline -ve & $6.00 \pm 0.00^{\mathrm{d}}$ & $6.00 \pm 0.00^{\mathrm{e}}$ & $6.00 \pm 0.00^{\mathrm{e}}$ & $6.00 \pm 0.00^{d}$ \\
\hline+ ve & $27.33 \pm 1.45^{\mathrm{a}}$ & $27.00 \pm 0.00^{\mathrm{a}}$ & $23.33 \pm 0.67^{\mathrm{a}}$ & $6.00 \pm 0.00^{\mathrm{d}}$ \\
\hline
\end{tabular}

Values are expressed as $\tilde{x} \pm S E M$; means which do not share a lowercase alphabet superscript within the same column are significantly different (One-Way ANOVA followed by Tukey's test $(p<0.05)$; Positive control: For E. coli and S. typhimurium it was Ciprofloxacin (10 $\mu \mathrm{g})$; For S. aureus it was Streptomycin $(\mu \mathrm{g})$ and for C. albicans it was Amphotericin B ( $\mu \mathrm{g})$; Negative control: DMSO (1.4 \%).

Table 3: Minimum inhibitory concentrations of the aqueous and methanolic extracts of Bridellia micrantha on selected microbial strains.

\begin{tabular}{|c|c|c|c|c|}
\hline \multirow{2}{*}{ Plant extract } & \multicolumn{4}{|c|}{ Minimum inhibitory concentration $(\mu \mathrm{g} / \mathrm{ml})$} \\
\hline & E. coli & S. typhimurium & S. aureus & C. albicans \\
\hline B. micrantha (aq) & 50 & 100 & 12.5 & 12.5 \\
\hline+ Ve control & 0.30 & 0.30 & 0.62 & $>100$ \\
\hline
\end{tabular}

Positive control: For E. coli and S. typhimurium it was Ciprofloxacin $(10 \mu \mathrm{g})$; For S. aureus it was Streptomycin ( $\mu \mathrm{g})$ and for C. albicans it was Amphotericin B ( $\mu \mathrm{g})$; aq: aqueous extract; met: Methanolic extract. 
Notably, the lowest MICs were recorded for aqueous bark extract of $B$. micrantha on S. aureus and C. albicans microbes (Table 3). Additionally, Ciprofloxacin (reference antibiotic) exhibited the lowest MICs on of $0.30 \mu \mathrm{g} / \mathrm{ml}$ on E. coli and S. typhimurium bacterial cultures while Streptomycin had an MIC of $0.62 \mu \mathrm{g} / \mathrm{ml}$ on $S$. aureus bacterial strain. Amphotericin B showed an MIC of $>100 \mu \mathrm{g} / \mathrm{ml}$ on C. albicans fungus. The MICs of the methanolic bark extract of B. micrantha were $50 \mu \mathrm{g} /$ $\mathrm{ml}$ for E. coli, $100 \mu \mathrm{g} / \mathrm{ml}$ for S. typhimurium and $12.5 \mu \mathrm{g} / \mathrm{ml}$ for both $S$. aureus and C. albicans microbes (Table 3 ).

Cytotoxic effects of the aqueous and methanolic extracts of the studied plants of Bridellia micrantha on brine shrimp nauplii

The effects of the studied plant extracts on brine shrimp nauplii were also investigated in this study. The concentrations of the aqueous and methanolic extracts of $B$. micrantha that could kill $50 \%$ of the exposed brine shrimp nauplii were determined and considered as mean lethal concentration $\left(\mathrm{LC}_{50}\right)$. Generally, the $\mathrm{LC}_{50}$ values ranged from $10 \mu \mathrm{g} /$ $\mathrm{ml}$ for the positive control (cyclophosphamide) to $486.67 \pm 3.15 \mu \mathrm{g} / \mathrm{ml}$ for the aqueous bark extract of $B$. micrantha (Table 4). The $\mathrm{LC}_{50}$ value obtained for the aqueous extract of $B$. micrantha was significantly higher than those of the methanolic extract of $B$. micrantha and the positive control drug $(\mathrm{p}<0.05$; Table 4$)$.

\section{Acute oral toxicity effects of the aqueous and methanolic extracts of Bridellia micrantha in rat models}

In this study, the acute oral toxicity effects of the aqueous and methanolic stem bark extracts of the studied plants in laboratory rats were evaluated. Various wellness parameters were monitored throughout the 14-day experiment period and the findings recorded.

The results showed that, at all the orally administered doses $(175 \mathrm{mg} / \mathrm{Kg}$ bw, $550 \mathrm{mg} / \mathrm{Kg}$ bw and $2000 \mathrm{mg} / \mathrm{Kg} \mathrm{bw}$ ) of the studied extracts, there were no observable signs of toxicity recorded in all the experimental rat models. Since the wellness parameters were normal to the limit dose level of $2000 \mathrm{mg} / \mathrm{Kg}$ bw, the $\mathrm{LD}_{50}$ values of all the studied plant extracts were considered to be $>2000 \mathrm{mg} / \mathrm{Kg}$ bw according to the OECD/OCDE (2008) guidelines.

\section{Qualitative phytochemical composition of aqueous and methanolic bark extracts of Bridellia micrantha}

The results showed presence of alkaloids, anthraquinones, saponins, tannins, glycosides, flavonoids and phenols in the aqueous and methanolic extracts of B. micrantha (Table 5).

\section{DISCUSSION}

The resurgences of multi-drug resistant microbial strains have rendered the management and treatment of associated infections a challenging endeavor, leading to increased morbidity and mortality ${ }^{22}$. It is estimated that annually, over 2 million persons are diagnosed with mortal infections which are exacerbated by resistance, and, of the diagnosed cases, over twenty thousand patients succumb as a result of therapeutic failure ${ }^{4,23}$. Globally, research has shown that antimicrobial resistance could cause over 10 million deaths by the year 2050 if not arrested early enough ${ }^{23}$.

Due to the inadequacy of therapeutic tools to thwart microbial infections, there is an urgent need for the search of alternative and complementary strategies to curb these infections ${ }^{22,24}$. As a result, medicinal plants have proved to be a viable alternative with a high propensity for potent antimicrobials ${ }^{25,26}$. As a result, the current study was designed to investigate the antimicrobial, cytotoxicity, acute oral toxicity effects, and phytochemical composition of the aqueous and methanolic stem bark extracts of $B$. micrantha. Since this plant is used traditionally to fight microbial infections, its scientific exploration serves as a guide towards the discovery of lead compounds for antimicrobial chemotherapy ${ }^{12,27}$.

We adopted the most recommended antimicrobial susceptibility methodology described by the $\mathrm{NCCLS}^{18}$, to determine the antimicrobial efficacy of the aqueous and methanolic stem bark extracts of $B$. micrantha. In this study, the standard disc diffusion and broth microdilution techniques were followed do determine the effects of the studied plant extracts on microbial growth. The zones of inhibition and the minimum inhibitory concentrations were considered indicators of antimicrobial activity.

Previous studies have shown that plant extracts exhibiting a zone of inhibition of above $6 \mathrm{~mm}$ on selected microbial strains have antimicrobial activity ${ }^{28-31}$. Plant extracts which show a zone of inhibition of between 6 $\mathrm{mm}$ and $9 \mathrm{~mm}$ are deemed to possess slight antimicrobial activity, those

Table 4: Effects of the aqueous and methanolic extracts of Bridellia micrantha brine shrimp nauplii.

\begin{tabular}{|cc|}
\hline Plant extract & $\mathrm{LC}_{50}(\mu \mathrm{g} / \mathrm{ml})$ \\
\hline C. megalocarpus (aq) & $486.67 \pm 3.15^{\mathrm{b}}$ \\
C. megalocarpus (met) & $458.33 \pm 2.87^{\mathrm{c}}$ \\
+ control & $10.00 \pm 1.31^{\mathrm{f}}$ \\
\hline
\end{tabular}

Values are presented as $\tilde{x} \pm S E M$; means with different lowercase alphabet superscript within the same column are significantly different by One-Way ANOVA followed by Tukey's test $(p<0.05)$; aq: aqueous extract; met: Methanolic extract; Positive control; cyclophosphamide.

Table 5: Presence of alkaloids, anthraquinones, saponins, tannins, glycosides, flavonoids and phenols in the aqueous and methanolic extracts of B. micrantha.

\begin{tabular}{|c|c|c|}
\hline \multirow{2}{*}{ Phytochemical } & \multicolumn{2}{|c|}{ B. micrantha } \\
\hline & Aqueous extract & Methanolic extract \\
\hline Alkaloids & + & + \\
\hline Tannins & + & + \\
\hline Glycosides & + & + \\
\hline Phenols & + & + \\
\hline
\end{tabular}

+: Present; -: Absent 
showing zones of between $9 \mathrm{~mm}$ and $12 \mathrm{~mm}$ have moderate activity while those exhibiting inhibition zones of $13-16 \mathrm{~mm}$ are considered to have high antimicrobial activity. Additionally, plant extracts which have inhibition zones ranging from $16-19 \mathrm{~mm}$ have very high antimicrobial activity while those exhibiting zones of inhibition with diameters of $20 \mathrm{~mm}$ or above on selected strains are considered to have remarkable antibiotic potency ${ }^{29,31,32}$.

In the present study, the aqueous extract of $B$. micrantha indicated slight to high antimicrobial activities against $E$. coli strain based on the produced zones of inhibition sizes. Slight to moderate effects were observed against $S$. typhimurium strain while moderate to high effects were exhibited on S. aureus bacterial strain and C. albicans fungal strain ${ }^{31}$.

For the methanolic extract of B. micrantha, moderate to high antimicrobial activities were recorded against $E$. coli while slight to moderate effects were observed in S. typhimurium strain. Slight to high and slight to very high antimicrobial effects were noted in S. aureus and C. albicans respectively. Remarkably, at a concentration of $100 \mu \mathrm{g} / \mathrm{ml}$ of the methanolic extract of B. micrantha a zone of $19.00 \pm 3.06 \mathrm{~mm}$ was recorded on C. albicans, indicating very high antifungal effects ${ }^{31}$. These findings corroborate those of Douglas and Gitonga ${ }^{33}$.

Moreover, research has shown that plant extracts which have MIC values that are less than $1 \mathrm{mg} / \mathrm{ml}(1000 \mu \mathrm{g} / \mathrm{ml})$ have antimicrobial activity with a potential of offering potent antibiotics ${ }^{14,34}$. In this study, the studied plant extracts exhibited low MIC values on selected microbes. Since the MIC values were much lower, it is anticipated that, the studied plant extracts can be strong antibiotics.

Medicinal plants are a host of various bioactive compounds with a broad spectrum of pharmacologic efficacies ${ }^{17}$. Research has shown that tannins, phenols, flavonoids, terpenoids among other phytocompounds are responsible for the antimicrobial activity of plants ${ }^{35-37}$. Therefore, bioactivities reported in this study are attributable to these phytochemicals which work either solely or in synergy with others to cause the pharmacologic effects.

Despite the long-standing utilization of herbals and their products for the management of various health conditions, serious concerns regarding their safety have been raised ${ }^{16}$. Various factors that affect the therapeutic potency of herbal medicines are generally not adhered to. There is lack of standard procedures and regulations governing the preparation, labelling, marketing and dispensing of herbal medicines ${ }^{15}$. This has led to an emergence of unscrupulous practioners of herbal medicine thereby raising safety concerns. There are no dosage guidelines, clearly outlines contraindications, conventional drugherbal drug interactions, and toxicity profiles of herbal preparations 38,39 . As a result, improper use of these medicines could cause lifethreatening effects considering the insufficiency of scientific and clinical data. Accordingly, we evaluated the cytotoxicity and acute oral toxicity effects of the aqueous and methanolic stem bark extracts of $B$. micrantha to appraise their safety.

We adopted the brine shrimp lethality assay technique described by Meyer et al. ${ }^{20}$ to assess the cytotoxic/safety effects of the aqueous and methanolic stem bark extracts of $B$. micrantha in exposed shrimp nauplii. In this method, the concentration of the plant extracts that can kill $50 \%$ of nauplii following exposure is considered as the $\mathrm{LC}_{50}$. Research has shown that plant extracts with $\mathrm{LC}_{50}$ values that are $<30$ $\mu \mathrm{g} / \mathrm{ml}$ are very cytotoxic. Furthermore, plant extracts exhibiting $\mathrm{LC}_{50}$ values ranging from $30-100 \mu \mathrm{g} / \mathrm{ml}$ are toxic, while those having $\mathrm{LC}_{50}$ values that are over $100 \mu \mathrm{g} / \mathrm{ml}$ are considered to be of low toxicity or safe ${ }^{40,41}$. Based on this criteria ${ }^{40,41}$, both the aqueous and methanolic extracts of $B$. micrantha were toxic as their $\mathrm{LC}_{50}$ values were between $30 \mu \mathrm{g} / \mathrm{ml}$ and $100 \mu \mathrm{g} / \mathrm{ml}$. Thus, caution should be exercised whenever extracts from B. micrantha are administered at cellular level to avert adverse events.
Since most of herbal medicines are administered orally, the acute oral toxicity effects of the studied plant extracts were investigated in rat models. In this study, the acute oral toxicity study top-down procedure described the OECD document number 425 was adopted ${ }^{21}$. The results showed that all the studied plant extracts were non-toxic at oral doses and therefore safe. Considering these results, the studied plant extracts are safe for use in traditional medicine.

It is however notable that both the aqueous and methanolic extracts of B. micrantha were toxic to brine shrimp but non-toxic to experimental mice. This could imply that multicellular organisms have efficient machineries and mechanisms of handling drug agents as opposed to unicellular and lower organisms ${ }^{42}$. Additionally, the toxicity exerted by these extracts at the cellular level could be negligible so as to cause no observable signs of toxicity in experimental rat models ${ }^{42,43}$. The safety of the studied plant extracts reported in this study could be attributed to low concentration or absence of toxicity associated phytochemical compounds ${ }^{44}$. Furthermore, the antimicrobial bioactive compounds anticipated to be present in the studied plant extracts in varied degrees do not cause observable signs of toxicity ${ }^{45}$. These findings indicate that the studied plant extracts can be good alternative sources of safe antimicrobial compounds. Therefore, this study supports the traditional use of the studied plant extracts for the management of the claimed conditions.

\section{CONCLUSIONS AND RECOMMENDATIONS}

Based on this study's findings, the aqueous and methanolic bark extracts of $B$. micrantha have appreciable antimicrobial effects on E. coli, S. typhimurium, S. aureus and C. albicans microbial strains. Also, the aqueous studied plant extracts of $B$. micrantha are toxic, to brine shrimp nauplii, but do not cause any observable signs of toxicity in experimental rats. Additionally, the aqueous and methanolic bark extracts of $B$. micrantha possess antimicrobial associated phytochemicals. Further investigations aimed at establishing the specific modes of action of the studied plant extracts are recommended. Moreover, drug interaction studies involving the studied plant extracts are encouraged. Further antimicrobial activity studies using other microbial strains, and toxicological investigations of the studied plant extracts in other experimental models should be done. Also, isolation and characterization of specific antimicrobial phytocompounds from the studied plant extracts should be done.

\section{DATA AVAILABILITY}

All data in this study are included within the manuscript; however, any additional information is available from authors upon request.

\section{CONFLICTS OF INTEREST}

The authors declare that there is no conflict of interest whatsoever regarding this study.

\section{AUTHOR CONTRIBUTIONS}

Joseph Kathare conceived the research idea and performed the experiments under the close supervision of James Mbaria and Joseph Nguta. Gervason Moriasi designed, guided the experiments, and assisted with data analysis and interpretation. All authors reviewed and approved the final manuscript for publication.

\section{FUNDING}

We did not receive any funding from any granting/funding agency/ corporation in the public or private sector. This study was solely achieved through our personal finances. 
Kathare JM, et al.: Antimicrobial Efficacy, Cytotoxicity, Acute Oral Toxicity, and Phytochemical Investigation of the Aqueous and Methanolic Stem Bark Extracts of Bridellia micrantha (Hochst.) Baill

\section{ACKNOWLEDGMENTS}

We acknowledge the Department of Public Health, Pharmacology, and Toxicology of the University of Nairobi for availing the lab facility, experimental animals, reagents, microbial strains, and equipment for this study. Also, we appreciate Mr. Maloba of the Department of Public Health, Pharmacology and Toxicology (UoN) and Mr. Nelson of the Department of Biological Sciences (MKU) for their technical assistance.

\section{REFERENCES}

1. Elston DM, Gibson LE, Kutzner H. Infectious diseases. In: Handbook of Practical Immunohistochemistry: Frequently Asked Questions. ; 2015. doi:10.1007/978-1-4939-1578-1_32

2. World Health Organization. WORLD HEALTH STATISTICS MONITORING HEALTH FOR THE SDGs. World Heal Organ. Published online 2016. doi:10.1017/CB09781107415324.004

3. World Health Organization. World Health Statistics 2012.; 2012.

4. Frieri M, Kumar K, Boutin A. Antibiotic resistance. J Infect Public Health. 2017;10(4):369-378. doi:10.1016/j.jiph.2016.08.007

5. Morens DM, Folkers GK, Fauci AS. The challenge of emerging and re-emerging infectious diseases. Nature. Published online 2004. doi:10.1038/nature02759

6. Cohen NR, Lobritz MA, Collins JJ. Microbial persistence and the road to drug resistance. Cell Host Microbe. Published online 2013. doi:10.1016/j.chom.2013.05.009

7. Hao H, Cheng $\mathrm{G}$, lqbal $\mathrm{Z}$, et al. Benefits and risks of antimicrobial use in food-producing animals. Front Microbiol. 2014;5(JUN):1-11. doi:10.3389/fmicb.2014.00288

8. WHO. WHO Traditional Medicine Strategy 2002-2005. World Heal Organ. Published online 2005:1-60.

9. WHO D. World HealthOrganization. Diarrhoea: Why Children Are Still Dying and What Can Be Done.; 2008.

10. Adeyemi IA, Omonigbehin AE, Stella S, Oluwatosin O, Jumoke S. Antibacterial activity of extracts of Alchornea cordifolia (Schum and Thonn) Mull.Arg., Boerhavia diffusa (L) and Bridellia micranthal (Hoscht) Baill. used in traditional medicine in Nigeria on Helicobacter pylori and four diarrhoeagenic bacterial pathoge. African $J$ Biotechnol. Published online 2008. doi:10.5897/AJB08.467

11. Kareru, P. G ., Kenji GM, , Gachanja, A. N., Keriko, J. M., \& Mungai $\mathrm{G}$. Traditional medicines among the Embu and Mbeere people of Kenya. Afr J Trad CAM. 2007;4(1):75-86

12. Maina JG. HERBAL MEDICINE USE IN MURANG ' A COUNTY AND ANTIFLEA ACTIVITY AND SAFETY OF TITHONIA DIVERSIFOLIA AND SENNA DIDYMOBOTRYA EXTRACTS BY GITHINJI , JAMES MAINA ( B . PHARM ) A Thesis Submitted in Partial Fulfillment for the Requirements of the Degree of Mast. Published online 2018.

13. Maroyi A. Ethnopharmacology and therapeutic value of Bridelia micrantha (Hochst.) Baill. in tropical Africa: A comprehensive review. Molecules. 2017;22(9). doi:10.3390/molecules22091493

14. Anyanwu MU, Okoye RC. Antimicrobial activity of Nigerian medicinal plants. J Intercult Ethnopharmacol. 2017;6(2):240-259. doi:10.5455/jice.20170106073231

15. Ekor M. The growing use of herbal medicines: Issues relating to adverse reactions and challenges in monitoring safety. Front Neurol. 2014;4 JAN(January):1-10. doi:10.3389/fphar.2013.00177

16. George P. Concerns regarding the safety and toxicity of medicinal plants - An overview. J Appl Pharm Sci. 2011;1(6):40-44.

17. Harborne JB. Phytochemical Methods A Guide To Modern Tecniques Of Plant Analysis, Third Edition. Chapman Hall. Published online 1998:58. doi:10.1017/CBO9781107415324.004

18. CLSI. M100-S23 Performance Standards for Antimicrobial.; 2014
19. Golus J, Sawicki R, Widelski J, Ginalska G. The agar microdilution method - a new method for antimicrobial susceptibility testing for essential oils and plant extracts. J App/ Microbiol. 2016;121(5):12911299. doi:10.1111/jam. 13253

20. Meyer B, Ferrihni NR, Putnam JE, Jacobsen LB, Nichols DE, McLaughilin JL. Brine Shrimp: A convenient general bioassay for active plant constituents. J Med Plamt Res. 1982;45:31-34. doi:10.3115/1220575.1220679

21. OECD. Test No. 425: Acute Oral Toxicity: Up-and-Down Procedure. 2008. doi:10.1787/9789264071049-en

22. Joray MB, Palacios SM, Carpinella MC. Understanding the interactions between metabolites isolated from Achyrocline satureioides in relation to its antibacterial activity. Phytomedicine. 2013;20(3-4):258-261. doi:10.1016/j.phymed.2012.10.015

23. WHO. I MPLEMENTATION OF THE GLOBAL ACTION PLAN ON Briefing: Protecting mothers and newborns from AMR AMR on Twitter Developing a National Action Plan : Thailand ' $s$ experience. 2016;(13):1-4

24. Yılmaz, Özcengiz G. Antibiotics: Pharmacokinetics, toxicity, resistance and multidrug efflux pumps. Biochem Pharmacol 2017:133:43-62. doi:10.1016/j.bcp.2016.10.005

25. Muthii RZ, Mucunu MJ, Peter MM, Stephen K, Onzago OR. Antimicrobial activity of aqueous and methanol extract of naturally growing and cultivated Aloe turkanensis. J Phytopharm. 2014;3(5):343-347

26. Kaminidevi S, Thangavelu T, Udayabhanu J, Thangavel SM Antimicrobial activity of methanolic extracts of indigenous traditional Indian folk Medicinal Plant, Gnaphalium polycaulon. Int J Green Pharm. 2015;9(1):39-44. doi:10.4103/0973-8258.150921

27. Amuka O, Okemo PO, Machocho AK, Mbugua PK. Ethnobotanica survey of selected medicinal plants used by Ogiek communities in Kenya against microbial infections. Ethnobot Res Appl. 2014:12(November):627-641. doi:10.17348/era.12.0.627-641

28. Jouda MM. The Antibacterial Effect of Some Medicinal Plant Extracts and their Synergistic Effect with Antibiotic and Nonantibiotic Drugs In the name of Allah, the Beneficent, the Merciful. Published online 2013.

29. Nanasombat S, Kuncharoen N, Ritcharoon B, Sukcharoen $P$ Antibacterial activity of thai medicinal plant extracts against oral and gastrointestinal pathogenic bacteria and prebiotic effect on the growth of lactobacillus acidophilus. Chiang Mai J Sci. 2018;45(1):33 44.

30. Atef NM, Shanab SM, Negm SI, Abbas YA. Evaluation of antimicrobial activity of some plant extracts against antibiotic susceptible and resistant bacterial strains causing wound infection. Bull Natl Res Cent. 2019;43(1). doi:10.1186/s42269-019-0184-9

31. Mwitari PG, Ayeka PA, Ondicho J, Matu EN, Bii CC. Antimicrobial Activity and Probable Mechanisms of Action of Medicinal Plants of Kenya: Withania somnifera, Warbugia ugandensis, Prunus africana and Plectrunthus barbatus. PLoS One. 2013;8(6):4-12. doi:10.1371/ journal.pone.0065619

32. Saquib SA, Alqahtani NA, Ahmad I, Kader MA, Al Shahrani SS, Asiri EA. Evaluation and comparison of antibacterial efficacy of herba extracts in combination with antibiotics on periodontal pathobionts: An in vitro microbiological study. Antibiotics. 2019;8(3):1-12. doi:10.3390/antibiotics8030089

33. Douglas K, Gitonga A. Antimicrobial Activity of Bridelia micrantha and Grewia plagiophylla Leaf Extracts. Br J Pharm Res. 2016;12(3):17. doi:10.9734/bjpr/2016/27270

34. Ezeja IM, Ezeigbo II, Madubuike KG, et al. Antidiarrheal activity of Pterocarpus erinaceus methanol leaf extract in experimentallyinduced diarrhea. Asian Pac J Trop Med. 2012;5(2):147-150. doi:10.1016/S1995-7645(12)60014-5 
Kathare JM, et al: Antimicrobial Efficacy, Cytotoxicity, Acute Oral Toxicity, and Phytochemical Investigation of the Aqueous and Methanolic Stem Bark Extracts of Bridellia micrantha (Hochst.) Baill

35. Kurmukov AG. Phytochemistry of medicinal plants. Med Plants Cent Asia Uzb Kyrg. 2013;1(6):13-14. doi:10.1007/978-1-46143912-7_4

36. Eldahshan OA, Singab ANB. Journal of Pharmacognosy and Phytochemistry. J Pharmacogn Phytochem Carotenoids. 2013;2(1):225-234

37. Molyneux RJ, Lee ST, Gardner DR, Panter KE, James LF. Phytochemicals: The good, the bad and the ugly? Phytochemistry. 2007;68(22-24):2973-2985. doi:10.1016/j.phytochem.2007.09.004

38. Kuete V, Sandjo LP, Mbaveng AT, Seukep JA, Ngadjui BT, Efferth T. Cytotoxicity of selected Cameroonian medicinal plants and Nauclea pobeguinii towards multi-factorial drug-resistant cancer cells. BMC Complement Altern Med. 2015;15(1). doi:10.1186/ s12906-015-0841-y

39. Saad B, Azaizeh H, Abu-Hijleh G, Said O. Safety of traditional Arab herbal medicine. Evidence-based Complement Altern Med. 2006;3(4):433-439. doi:10.1093/ecam/nel058

40. Gadir SA. Assessment of bioactivity of some Sudanese medicinal plants using brine shrimp (Artemia salina) lethality assay. J Chem Pharm Res. 2012;4(12):5145-5148.
41. Moshi MJ, Innocent E, Magadula JJ, et al. Brine shrimp toxicity of some plants used as traditional medicines in Kagera Region, north western Tanzania. Tanzan J Health Res. 2010;12(1):7. doi:10.4314/ thrb.v12i1.56287

42. Sahgal G, Ramanathan S, Sasidharan S, Mordi MN, Ismail S, Mansor SM. Brine shrimp lethality and acute oral toxicity studies on Swietenia mahagoni (Linn.) Jacq. seed methanolic extract. Pharmacognosy Res. 2010;2(4):215-220. doi:10.4103/0974-8490.69107

43. Naidu JR, Ismail R, Sasidharan S. Acute oral toxicity and brine shrimp lethality of methanol extract of Mentha Spicata L (Lamiaceae). Trop J Pharm Res. 2014;13(1):101-107. doi:10.4314/tjpr.v13i1.15

44. Bode AM, Dong Z. Toxic phytochemicals and their potential risks for human cancer. Cancer Prev Res. 2015;8(1):1-8. doi:10.1158/19406207.CAPR-14-0160

45. Riaz B, Zahoor MK, Zahoor MA, et al. Toxicity, Phytochemical Composition, and Enzyme Inhibitory Activities of Some Indigenous Weed Plant Extracts in Fruit Fly, Drosophila melanogaster. Evidence-based Complement Altern Med. 2018;2018. doi:10.1155/2018/2325659.

\section{GRAPHICAL ABSTRACT}

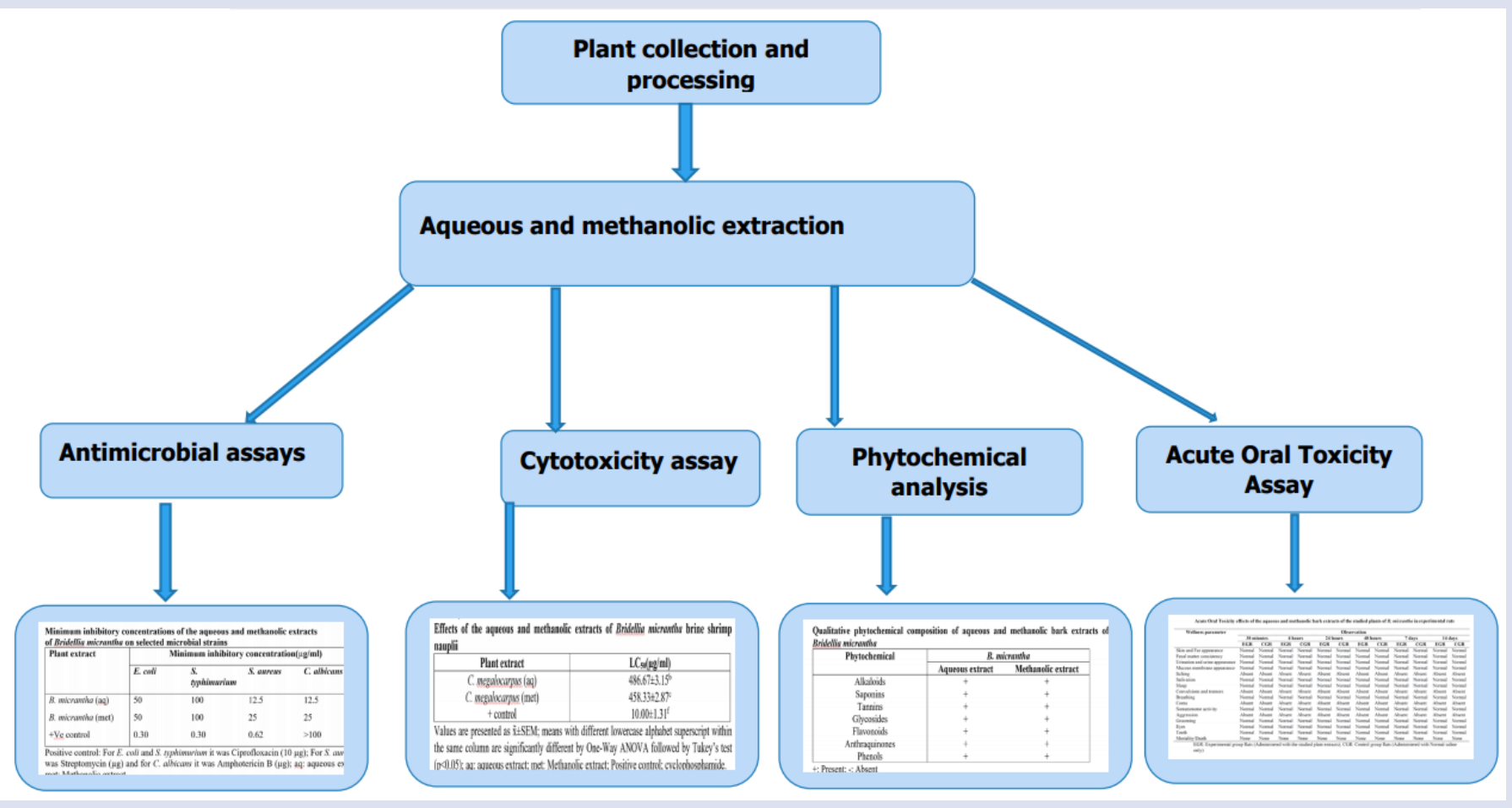




\section{ABOUT AUTHORS

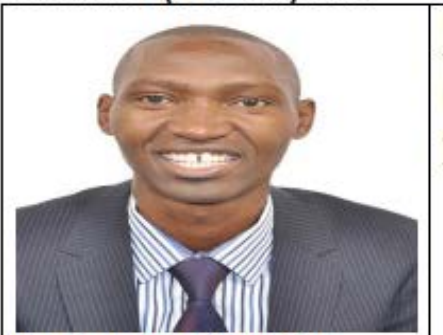 \\ Dr. Joseph M. Kathare is a registered pharmacist and medication therapy management (MTM) specialist. $\mathrm{He}$ is a holder of a Bachelor of Pharmacy (BPharm) degree, and currently pursuing a Master of Science degree in pharmacology and toxicology at the University of Nairobi. \\ Dr. Joseph Murithi Kathare

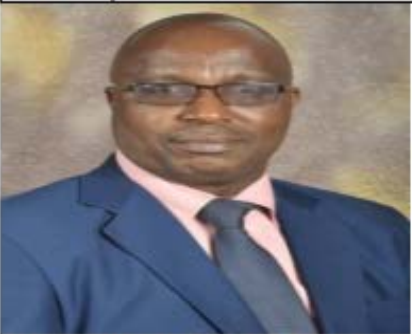 \\ Prof. James Mucunu Mbaria

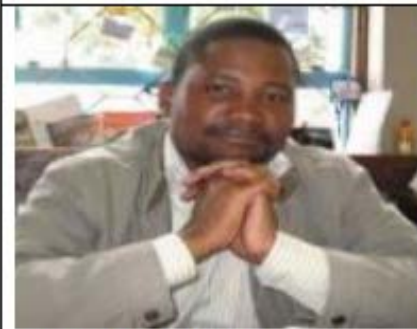 \\ Dr. Joseph Mwanzia Nguta

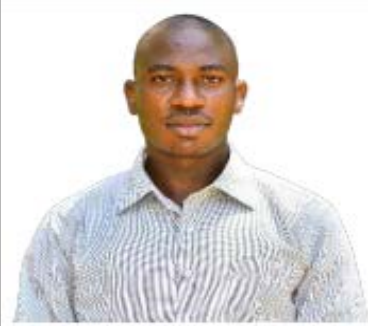 \\ Dr. Gervason Apiri Moriasi \\ Prof. James M. Mbaria is a Pharmacologist/Toxologist and currently the Chairman of the Department of Public Health, Pharmacology and Toxicology at the University of Nairobi. He is a holder Bachelor of Veterinary Medicine (BVM), Master of Science and PhD in Pharmacology \& Toxicology. He is an experienced researcher having provided academic leadership, teaching and consultancy at University level over 32 years. Prof Mbaria has published more 125 scholarly articles in refereed journals, learning modules, book chapters and conference proceedings. \\ Dr. Joseph M. Nguta is a Veterinary surgeon (BVM Degree) by training and Pharmacologist and Toxicologist by specialization. $\mathrm{He}$ is a Senior Lecturer at the Department of Public Health, Pharmacology and Toxicology (PHPT), University of Nairobi. Dr. Nguta has a cumulative citation of $\mathbf{8 1 2}$, h-index of 13 and i10- index of 18. He has special research interests in Natural Product Pharmacology and Toxicology, specifically, antimicrobial drug discovery from microbial and floral biodiversity. \\ Dr. Gervason A. Moriasi is a Laboratory Medicine practitioner with over 10 years' experience. He holds a Bachelor of Science in Biochemistry, Cellular and Molecular Biology, and a Master of Science of degree in Medical Biochemistry, and currently pursuing his Doctor of Philosophy (PhD) in Medical Biochemistry. He is also a qualified Biochemical pathologist, and Consultant by training and experience. He is a Human Health Researcher, with 24 research publications in internationally refereed journals. He currently works as a faculty of medicine staff and Human Health Researcher at Mount Kenya University, and an adjunct faculty at Kenyatta University, Kenya.}

Cite this article: Kathare JM, Mbaria JM, Nguta JM, Moriasi GA, Mainga AO. Antimicrobial Efficacy, Cytotoxicity, Acute Oral Toxicity, and Phytochemical Investigation of the Aqueous and Methanolic Stem Bark Extracts of Bridellia micrantha (Hochst.) Baill. Pharmacogn J. 2021;13(5): 1248-1256. 